\title{
PENERAPAN E-GOVERNMENT DALAM MENINGKATKAN KUALITAS PELAYANAN PUBLIK DI DINAS PENANAMAN MODAL DAN PELAYANAN TERPADU SATU PINTU KOTA BANDUNG PROVINSI JAWA BARAT
}

\author{
Oleh \\ Andana Adytia Kusuma ${ }^{1}$, \\ Sadu Wasistiono ${ }^{2}$, Andi Pitono ${ }^{3}$ \\ 1) Pemerintah Pemerintah Provinsi Jambi \\ Program Magister Terapan Studi Pemerintahan Daerah Institut Pemerintahan Dalam Negeri \\ vaandhana07@yahoo.com \\ 2,3) Institut Pemerintahan Dalam Negeri
}

\begin{abstract}
"IMPLEMENTATION OF E-GOVERNMENT IN IMPROVING THE QUALITY OF PUBLIC SERVICE IN DEPARTMENT OF INVESTMENT SERVICE AND INTEGRATED SERVICE IN BANDUNG CITY, WEST JAVA PROVINCE"
\end{abstract}

$T$

he use of digital technology gave birth to a new form of government bureaucratic mechanism with the term electronic-government. The focus of this research is to look the implementation of e-government in improving the quality of public services in Departement of Investment Service and Integrated Service of One Door (DPM-PTSP) Bandung City, the factors that influence and determine the strategies used to implement e-government in improving quality public service at DPM-PTSP Bandung City.

The research uses theory by Indrajit related to the implementation of e-government and perform direct interview to know the factors that influence and conduct a SWOT analysis and litmus test to determine strategies. This research uses a qualitative method with a descriptive approach. In collecting data, researchers conducted observations, interviews, collected documents and do data triangulation on the implementation of e-government in improving the quality of public services at the DPM-PTSP Bandung City.

The results showed that the implementation of e-government in improving the quality of public services in DPM-PTSP Bandung City had run adequately. Judging from the elements of support for the implementation of e-government, it has been supported by e-government policies from the Central Government level to the Regional Apparatus Organizations, but the socialization that has been carried out is still not optimal. In the element of capacity, the application of e-government has been supported by adequate budget, technology infrastructure and employee competencies, on the value element the application of e-government has provided benefits for the community and government.

Steps that can be done by DPM-PTSP Bandung City in implementing e-government in improving the quality of public service including: (1) Coordinate with the central government regarding the commitment to implementing online licensing services and easy access to public information through the website/application; (2) Integrate HAYU and GAMPIL with licensing service applications from the central government; (3) To socialize the application of e-government directly to the 
public; (4) Conduct regular application security level audits; (5) Cooperate with technical offices to improve service quality; (6) Make plans for employee needs and the required formations; (7) Increase the capacity of the apparatus through public service training and training in the field of ICT; (8) Carry out wider outreach on process digitization innovations to narrow the space for intermediaries to move; (9) Carrying out communication and coordination forums with relevant regional officials to maximize the quality of the e-government-based licensing service process; (10) Optimizing the functions and competencies of employees to carry out their respective duties in implementing e-government in licensing services; (11) Create special counters for people who need direct guidance.

Keywords: implementation of e-government, quality of public services, PTSP

\section{AbSTRAK}

$\mathrm{P}$ emanfaatan teknologi digital melahirkan sebuah bentuk mekanisme birokrasi pemerintahan yang baru dengan istilah pemerintahan-elektronik (electronic-government). Fokus dari penelitian ini adalah melihat penerapan e-government dalam meningkatkan kualitas pelayanan publik pada Dinas Penanaman Modal dan Pelayanan Terpadu Satu Pintu (DPM-PTSP) Kota Bandung, faktor-faktor yang memengaruhi serta menentukan strategi yang sebaiknya dilakukan untuk keberhasilan penerapan e-government dalam meningkatkan kualitas pelayanan publik di DPM-PTSP Kota Bandung.

Peneliti menggunakan teori oleh Indrajit terkait penerapan e-government dan melaksanakan wawancara langsung untuk mengetahui faktor-faktor yang memengaruhi serta melakukan analisis SWOT dan litmus test untuk menentukan strategi. Penelitian ini menggunakan metode kualitatif dengan pendekatan deskriptif. Dalam mengumpulkan data, peneliti melakukan observasi, wawancara, mengumpulkan dokumen, dan triangulasi data tentang penerapan e-government dalam meningkatkan kualitas pelayanan publik pada DPMPTSP Kota Bandung.

Hasil penelitian menunjukkan bahwa penerapan e-government dalam meningkatkan kualitas pelayanan publik pada DPM-PTSP Kota Bandung sudah cukup baik. Dilihat dari elemen support penerapan e-government telah didukung oleh kebijakan e-government dari tingkat Pemerintah Pusat sampai ke Organisasi Perangkat Daerah, namun sosialisasi yang dilaksanakan masih belum maksimal, Pada elemen capacity penerapan e-government telah didukung oleh anggaran, infrastruktur teknologi dan kompetensi pegawai yang memadai, pada elemen value penerapan e-governmentt telah memberikan manfaat bagi masyarakat dan pemerintah.

Langkah-langkah yang dapat dilakukan DPM-PTSP Kota Bandung pada penerapan e-government dalam meningkatkan kualitas pelayanan publik antara lain: (1) Berkoordinasi dengan pemerintah pusat mengenai komitmen penerapan pelayanan perizinan secara online dan kemudahan akses informasi publik melalui website/aplikasi; (2) Mengintegrasikan HAYU dan GAMPIL dengan aplikasi pelayanan perizinan dari pemerintah pusat; (3) Melakukan sosialisasi penerapan e-government langsung kepada masyarakat; (4) Melaksanakan audit tingkat keamanan aplikasi secara berkala; (5) Bekerja sama dengan dinas teknis untuk meningkatkan kualitas pelayanan; (6) Membuat rencana kebutuhan pegawai dan formasi yang dibutuhkan; (7) Meningkatkan kapasitas aparatur melalui pelatihan pelayanan publik dan pelatihan di bidang TIK; (8) Melaksanakan sosialisasi lebih luas mengenai inovasi digitalisasi proses untuk mempersempit ruang gerak calo; (9) Melaksanakan forum komunikasi dan koordinasi dengan perangkat daerah terkait untuk memaksimalkan kualitas proses pelayanan perizinan berbasis e-government; (10) Mengoptimalkan fungsi dan kompetensi pegawai untuk melaksanakan tugas masing-masing pada penerapan e-government dalam pelayanan perizinan; (11) Membuat loket khusus bagi masyarakat yang membutuhkan panduan secara langsung.

Kata kunci: penerapan e-government, kualitas pelayanan publik, PTSP 


\section{PENDAHULUAN}

$\mathrm{P}$ emanfaatan Teknologi Informasi dan Komunikasi (TIK) telah merambah di dunia pemerintahan. Di negaranegara maju, hasil dari pemanfaatan teknologi digital (electronic digital service) telah melahirkan sebuah bentuk mekanisme birokrasi pemerintahan yang baru, sehingga muncullah istilah pemerintahan-elektronik (electronicgovernment).

Di Indonesia sendiri telah disusun kebijakan strategis penerapan Teknologi Informasi dan Komunikasi (TIK) untuk dunia pemerintahan melalui Instruksi Presiden No. 3 Tahun 2003 tentang Kebijakan dan Strategi Nasional Pengembangan $e$-Government, yang merupakan upaya untuk mengembangkan penyelenggaraan kepemerintahan yang berbasis (menggunakan) elektronik dalam rangka meningkatkan kualitas layanan publik secara efektif dan efisien.

Penerapan e-government di Indonesia belum begitu maksimal. Hal ini tampak dari hasil survei PBB mengenai peringkat E-Government Development Index (EGDI). Berdasarkan hasil survei tersebut pada 2018, Indonesia berada di peringkat 107 dari 193 negara di dunia soal penerapan $e$-Government. Hal tersebut menunjukkan bahwa kualitas e-government di Indonesia masih harus ditingkatkan (https:// www.liputan6.com/tekno/read/2499161/ opini-cegah-penyelewengan-dengan-e-government-hybrid-cloud-diakses pada 1 November 2019).

Berlakunya Undang-Undang No. 23 Tahun 2014 tentang Pemerintahan Daerah juga telah mengubah sistem pemerintahan yang semula sentralisasi menjadi desentralisasi sehingga memungkinkan terjadinya penyelenggaraan pelayanan dengan jalur birokrasi yang lebih ringkas.

Menciptakan iklim investasi yang kondusif dengan memberikan pelayanan yang transparan, perlakuan yang sama, mudah, efisien, cepat, berkeadilan, akuntabilitas, dan kepastian hukum, diperlukan pelayanan di bidang penanaman modal, baik pelayanan perizinan maupun Non-perizinan yang dilaksanakan secara terpadu satu pintu, dengan sebutan lain, yaitu Pelayanan Terpadu Satu Pintu (PTSP).

Pelayanan Terpadu Satu Pintu (PTSP) adalah kegiatan penyelenggaraan suatu perizinan dan non-perizinan yang mendapat pendelegasian atau pelimpahan wewenang dari lembaga atau instansi yang memiliki kewenangan perizinan dan Non-perizinan di mana proses pengelolaannya dimulai dari tahap permohonan sampai dengan tahap terbitnya dokumen yang dilakukan dalam satu tempat.

Suka atau tidak suka perubahan harus tetap dilaksanakan demi beradaptasi dengan perkembangan zaman dan dapat menjawab tuntutan masyarakat yang semakin besar akan pelayanan yang lebih baik agar terciptanya manajemen pemerintah menjadi agile governance (tata kelola yang gesit). Menurut Schwab (2016: 68),

"Agile governance means that regulators must find ways to adapt continuously to a new, fast changing environment by reinventing themselves to understand better what they are regulating."

Penggunaan komputer atau teknologi informasi di dalam proses pemerintahan belum berarti bahwa konsep e-government telah diterapkan, karena belum tentu kehadiran benda tersebut dapat mengubah kinerja pemerintah. Memfokuskan diri terus menerus pada pembaruan dan pengadaan berbagai macam teknologi dalam pengembangan e-government adalah sebuah langkah yang keliru. Perlu dipahami bahwa teknologi hanyalah merupakan instrument untuk terciptanya sebuah transformasi peranan pemerintah, dari yang bersifat birokrasi, menjadi sebuah "lembaga" yang berorientasi proses untuk melayani "pelanggannya" - yang dalam hal ini adalah 
masyarakat, komunitas bisnis (industri), dan para stakeholder lainnya. (Indrajit et al., 2007).

Berdasarkan permasalahan yang telah diuraikan di atas maka fokus penelitian adalah penerapan electronic government (e-gov) dalam meningkatkan kualitas pelayanan publik di Dinas Penanaman Modal dan Pelayanan Terpadu Satu Pintu (DPMPTSP) Kota Bandung. Kemudian berdasarkan uraian di atas, maka dapat dirumuskan permasalahan yang akan menjadi fokus dalam penelitian ini sebagai berikut.

1. Bagaimanakah penerapan electronic government (e-gov) dalam meningkatkan kualitas pelayanan publik di Dinas Penanaman Modal dan Pelayanan Terpadu Satu Pintu Kota Bandung?

2. Faktor apa sajakah yang memengaruhi penerapan electronic government (e-gov) dalam meningkatkan kualitas pelayanan publik di Dinas Penanaman Modal dan Pelayanan Terpadu Satu Pintu Kota Bandung?

3. Strategi apakah yang sebaiknya dilakukan untuk keberhasilan penerapan electronic government (e-gov) dalam meningkatkan kualitas pelayanan publik di Dinas Penanaman Modal dan Pelayanan Terpadu Satu Pintu Kota Bandung?

Penelitian ini bermaksud untuk mengetahui dan menganalisis tentang penerapan electronic government (e-gov) di dinas penanaman modal dan pelayanan terpadu satu pintu kota bandung, kemudian diketahui faktor-faktor yang memengaruhi dan strategi-strategi yang akan digunakan untuk keberhasilan penerapan e-gov dalam meningkatkan kualitas pelayanan publik di Dinas Penanaman Modal dan Pelayanan Terpadu Satu Pintu (DPM-PTSP) Kota Bandung.

Adapun tujuan dari penelitian ini adalah sebagai berikut.
1. Untuk memperoleh gambaran/deskripsi tentangpenerapanelectronicgovernment (e-gov) dalam meningkatkan kualitas pelayanan publik di Dinas Penanaman Modal dan Pelayanan Terpadu Satu Pintu Kota Bandung.

2. Untuk memperoleh gambaran/deskripsi tentang faktor-faktor yang memengaruhi penerapan electronic government (e-gov) dalam meningkatkan kualitas pelayanan publik di Dinas Penanaman Modal dan Pelayanan Terpadu Satu Pintu Kota Bandung.

3. Untuk merumuskan strategi yang sebaiknya digunakan untuk keberhasilan penerapan electronic government (e-gov) dalam meningkatkan kualitas pelayanan publik di Dinas Penanaman Modal dan Pelayanan Terpadu Satu Pintu Kota Bandung.

\section{KAJIAN PUSTAKA}

\section{Pemerintahan}

Secara umum pengertian pemerintahan menurut Sumaryadi (2010: 16) bahwa "pemerintah dapat didefinisikan sebagai organisasi yang memiliki kekuasaan untuk membuat dan merapatkan hukum serta undang-undang di wilayah tertentu". Kemudian dijelaskan oleh Sumaryadi (2010: 16) bahwa:

Pemerintah merupakan sebuah organisasi yang memiliki: 1) otoritas memerintah dari sebuah unit politik; 2) kekuasaan yang memerintah suatu masyarakat politik (political); 3) apparatus yang merupakan badan pemerintahan yang berfungsi dan menjalankan kekuasaan; 4) kekuasaan untuk membuat Peraturan Perundang-Undangan untuk menangani perselisihan dan membacakan putusan administrasi dan dengan monopoli atas kekuasaan yang sah.

Definisi pemerintahan daerah berdasarkan Undang-Undang No. 23 Tahun 
2014 adalah penyelenggaraan urusan pemerintahan oleh pemerintah daerah dan dewan perwakilan rakyat daerah menurut asas otonomi dan tugas pembantuan dengan prinsip otonomi seluas-luasnya dalam sistem dan prinsip Negara Kesatuan Republik Indonesia sebagaimana dimaksud dalam Undang-Undang Dasar 1945.

\section{Pemerintahan Elektronik (Electronic Government)}

Dijelaskan dalam Indrajit (2006: 2) bahwa prinsip e-government berawal dari kekhawatiran Bank Dunia sebagai lembaga dunia dalam mengantisipasi permasalahan globalisasi seperti ekonomi, sosial, budaya, politik, dan hukum. Indrajit (2006: 15) menyatakan untuk menerapkan konsepkonsep digitalisasi pada sektor publik, ada tiga elemen sukses yang harus dimiliki dan diperhatikan sungguh-sungguh. Masingmasing elemen tersebut adalah sebagai berikut.

\section{- Support}

Elemen pertama dan paling krusial yang harus dimiliki oleh pemerintah adalah keinginan (intent) dari berbagai kalangan pejabat publik dan politik untuk benarbenar menerapkan konsep e-government. Tanpa adanya unsur "political will" ini, mustahil berbagai inisiatif pembangunan dan pengembangan e-government dapat berjalan dengan mulus. Bentuk dukungan yang dapat dilakukan adalah dalam bentuk hal-hal sebagai berikut.

a. Disepakatinya kerangka/kebijakan e-government sebagai salah satu kunci sukses negara dalam mencapai visi dan misi bangsanya, sehingga harus diberikan prioritas tinggi sebagaimana kunci-kunci sukses lain diperlukan;

b. Disosialisasikannya konsep e-government secara merata, kontinyu, konsisten, dan menyeluruh kepada seluruh kalangan birokrat secara khusus dan masyarakat secara umum melalui berbagai cara kampanye yang simpatik.

\section{- Capacity}

Yang dimaksud dengan elemen kedua adalah adanya unsur kemampuan atau keberdayaan dari pemerintah setempat dalam mewujudkan "impian" e-government terkait menjadi kenyataan. ada tiga hal minimum yang paling tidak harus dimiliki oleh pemerintah sehubungan dengan elemen berikut ini.

a. Ketersediaan sumber daya finansial yang cukup untuk melaksanakan berbagai inisiatif e-government;

b. Ketersediaan infrastruktur teknologi informasi yang memadai karena fasilitas ini merupakan lima puluh persen dari kunci keberhasilan penerapan e-government; dan

c. Ketersediaan sumber daya manusia yang memiliki kompetensi dan keahlian yang dibutuhkan agar penerapan e-government dapat sesuai dengan asas manfaat yang diharapkan.

\section{- Value}

Elemen value berdasarkan pada manfaat yang didapat oleh pemerintah sebagai pemberi pelayanan dan juga masyarakat sebagai penerima pelayanan e-government. Dalam elemen value yang menentukan besar tidaknya manfaat yang diperoleh dengan adanya e-government bukanlah kalangan pemerintah sendiri, melainkan masyarakat dan mereka yang berkepentingan (demand side) sebagai penerima pelayanan. Untuk itulah maka pemerintah harus benar-benar teliti dalam memilih prioritas jenis aplikasi e-government yang harus didahulukan agar benar-benar memberikan value (manfaat) yang secara signifikan dirasakan oleh masyarakatnya. 


\section{Kualitas Pelayanan Publik}

Menurut Sumaryadi (2016: 112) "pelayanan merupakan salah satu perwujudan dari fungsi aktor pemerintahan sebagai abdi masyarakat untuk menyejahterakan masyarakat dari satu negara kesejahteraan (welfare state)".

Kurniawan dalam Sinambela (2010: 5) mengartikan pelayanan publik sebagai, "pemberian layanan (melayani) keperluan orang atau masyarakat yang mempunyai kepentingan pada organisasi itu sesuai dengan aturan pokok dan tata cara yang telah ditetapkan".

Kualitas pelayanan menurut Ibrahim (2008: 22) dijelaskan bahwa "sebagai suatu kondisi dinamis yang berhubungan dengan produk, jasa, manusia, proses dan lingkungan yang memenuhi atau bahkan mungkin melebihi harapan". Ibrahim (2008: 22) juga menjelaskan kualitas pelayanan juga diartikan sebagai "sesuatu yang berhubungan dengan terpenuhinya harapan/ kebutuhan pelanggan (masyarakat), di mana pelayanan dikatakan berkualitas apabila dapat menyediakan produk dan atau jasa sesuai dengan kebutuhan para pelanggan (masyarakat)".

Pelayanan yang berkualitas juga dapat dilakukan dengan konsep "layanan sepenuh hati". Layanan sepenuh hati yang digagas oleh Patricia Patton dalam Sinambela (2010: 8) "dimaksudkan layanan yang berasal dari diri sendiri yang mencerminkan emosi, watak, keyakinan, nilai, sudut pandang, dan perasaan"

\section{Pelayanan Terpadu Satu Pintu}

Berdasarkan Peraturan Pemerintah No. 18 Tahun 2016 tentang Perangkat Daerah, maka pembentukan unit pelayanan terpadu satu pintu merupakan suatu keharusan. Seperti yang termaktub dalam Peraturan Pemerintah No. 18 Tahun 2016 tentang Perangkat Daerah pada Pasal 17 ayat (1) yaitu sebagai berikut.
Untuk meningkatkan kualitas pelayanan perizinan dan Non-perizinan kepada masyarakat, daerah membentuk unit pelayanan terpadu satu pintu daerah provinsi yang melekat pada dinas daerah provinsi yang menyelenggarakan Urusan Pemerintahan di bidang Penanaman Modal.

Mengimplementasikan Peraturan Pemerintah No. 18 Tahun 2016 tentang Perangkat Daerah, maka Wali Kota Bandung membentuk Unit Pelayanan Terpadu Satu Pintu dengan melekat pada dinas yang menyelenggarakan urusan penanaman modal sehingga terbentuklah Dinas Penanaman Modal dan Pelayanan Terpadu Satu Pintu Kota Bandung melalui Peraturan Daerah Kota Bandung No. 8 Tahun 2016 tentang Pembentukan dan Susunan Perangkat Daerah Kota Bandung.

Peraturan Kepala Badan Koordinasi Penanaman Modal Republik Indonesia No. 15 Tahun 2015 tentang Pedoman dan Tata Cara Perizinan dan Non-Perizinan Penanaman Modal Pasal 1 ayat (5) disebutkan bahwa:

Pelayanan Terpadu Satu Pintu, yang selanjutnya disingkat PTSP, adalah pelayanan secara terintegrasi dalam satu kesatuan proses dimulai dari tahap permohonan sampai dengan tahap penyelesaian produk pelayanan melalui satu pintu.

\section{METODE PENELITIAN}

Penelitian menurut L.R. Gray dalam Sumanto (2014: 4) adalah "penggunaan metode ilmiah secara formal dan sistematis untuk menjawab dan menyelesaikan masalah". Menurut Nazir (2014: 70) "penelitian adalah proses mencari sesuatu secara sistematik dalam waktu yang dengan menggunakan metode ilmiah serta aturanaturan yang berlaku".

Menurut Effendi (2014: 117) bahwa "penelitian kualitatif adalah penelitian yang menjelaskan dan menganalisis perilaku 
manusia secara individual dan kelompok prinsip atau kepercayaan, pemahaman atau pemikiran, dan persepsi atau tanggapan. Selanjutnya menurut Creswell (2014: 4) dijelaskan penelitian kualitatif adalah "metode-metode yang digunakan untuk mengeksplorasi dan memahami makna yang oleh sejumlah individu atau sekelompok orang dianggap berasal dari masalah sosial atau kemanusiaan".

Whitney dalam Nazir (2014: 43) metode deskriptif adalah "pencarian fakta dengan interpretasi yang tepat dengan mempelajari masalah-masalah dalam masyarakat serta tata cara yang berlaku dalam masyarakat, termasuk hubungan kegiatan, sikap, pandangan serta proses yang berlangsung dan pengaruh dari suatu fenomena".

Desain penelitian menggunakan metode kualitatif dengan pendekatan deskriptif yang merupakan suatu proses penjajakan atau penggalian suatu permasalahan secara mendalam dan komprehensif dari kumpulan informasi yang pada akhirnya bertujuan untuk menggambarkan permasalahan. Kemudian pengumpulan data pada penilitian menggunakan informan sebagai sumber informasi, kemudian teknik pengumpulan data dengan cara wawancara, observasi, dokumentasi dan triangulasi. Selanjutnya langkah-langkah dalam analisis data yang dilakukan peneliti melalui reduksi data, penyajian data, dan penarikan simpulan.

\section{HASIL PENELITIAN DAN PEMBAHASAN}

\section{Penerapan E-Government dalam Meningkatkan Kualitas Pelayanan Publik di DPM-PTSP Kota Bandung}

Dalam memperoleh data-data penerapan e-government dalam meningkatkan kualitas pelayanan publik ini, peneliti menggunakan elemen sukses penerapan e-government dalam Indrajit (2006), yaitu support, capacity, dan value.
Elemen support merupakan elemen pertama dan dapat dilihat dari bentuk dukungan kerangka/kebijakan e-government dan sosialisasi konsep e-government. Berdasarkan beberapa informasi dan data lapangan maupun dokumen dapat diketahui bahwa sudah adanya kebijakan e-government dari tingkat Pemerintah Pusat, lingkup Pemerintah Kota Bandung, kemudian diteruskan dengan kebijakan e-government di lingkup Dinas Penanaman Modal dan Pelayanan Terpadu Satu Pintu Kota Bandung. Berdasarkan dari informasi wawancara berbagai informan dan pengamatan di lapangan dapat diketahui bahwa sosialisasi sudah dilakukan namun belum menyeluruh, baru terbatas kepada kalangan aparatur pemerintah dan target group UMKM belum kepada masyarakat secara luas.

Elemen kedua, yaitu capacity di mana terdapat tiga sumber daya yang harus dimiliki dalam elemen tersebut, yaitu sumber daya finansial (anggaran), infrastruktur teknologi informasi, sumber daya manusia yang kompeten. Berdasarkan hasil wawancara berbagai informan dan data penelitian di lapangan, dapat diketahui bahwa sumber daya finansial (anggaran) dirasa sudah cukup dan tidak ada kendala finansial dalam mendukung kegiatan pelayanan perizinan yang berbasis digital di DPM-PTSP Kota Bandung. Ketersediaan infrastruktur teknologi informasi penerapan e-government dalam pelayanan publik di Dinas Penanaman Modal dan Pelayanan Terpadu Satu Pintu Kota Bandung cukup lengkap dan didukung dengan jaringan internet melalui Local Area Network (LAN) dan Wireless Fidelity (WiFi) serta Pegawai di Dinas Penanaman Modal dan Pelayanan Terpadu Satu Pintu Kota Bandung memiliki tingkat pendidikan yang baik, kompetensi dan profesionalisme yang terjaga.

Elemen value berdasarkan pada manfaat yang didapat oleh pemerintah sebagai pemberi pelayanan dan juga masyarakat sebagai penerima pelayanan 
e-government. Manfaat yang dihasilkan untuk masyarakat adalah masyarakat dapat merasakan pelayanan publik yang lebih baik dalam bentuk efisiensi pelayanan serta meningkatkan minat pelaku usaha untuk melakukan investasi dan pengembangan usaha di Kota Bandung. Sementara manfaat yang dihasilkan untuk pemerintah adalah sejauh mana pemerintah dapat mengurangi beban administratif karena pelayanan yang lebih efektif dan efisien.

\section{Faktor yang Memengaruhi Penerapan E-Government}

Peneliti menemukan empat faktor pendukung penerapan e-gov dalam meningkatkan kualitas pelayanan publik pada Dinas Penanaman Modal dan Pelayanan Terpadu Satu Pintu Kota Bandung, yaitu anggaran dan infrastruktur memadai, adanya regulasi dan kepastian hukum, adanya transparansi, dan terjadinya perubahan proses administrasi.

Setiap adanya suatu pelayanan, pasti ada kendala dan masalah yang menjadi faktor penghambat untuk kesuksesan sebuah pelayanan tersebut. Berdasarkan hasil dari penelitian peneliti menemukan empat faktor penghambat penerapan e-gov dalam meningkatkan kualitas pelayanan publik pada Dinas Penanaman Modal dan Pelayanan Terpadu Satu Pintu Kota Bandung, yaitu kekurangan sumber daya manusia, belum adanya integrasi sistem, minimnya pengetahuan masyarakat, dan adanya tumpang tindih peraturan perizinan.

\section{Strategi yang Digunakan untuk Keber- hasilan Penerapan E-Government}

Teknik yang digunakan peneliti dalam menganalisis dan menyusun strategi adalah dengan menggunakan teknis analisis SWOT. Analisis SWOT dapat diterapkan dengan cara menganalisis dan memilih berbagai hal yang memengaruhi variabel, yakni kekuatan (strengths), kelemahan (weakness), peluang (opportunities), dan ancaman (threats) yang kemudian diterapkan dalam matriks SWOT, maka hasil analisis SWOT yang dapat peneliti simpulkan berdasarkan hasil wawancara dan pengamatan peneliti di lapangan adalah sebagai berikut.

1. Kekuatan (Strengths)

a) Anggaran dan infrastruktur pendukung memadai;

b) Adanya regulasi dan kepastian hukum mengenai penerapan e-government;

c) Adanya transparansi;

d) Adanya aplikasi e-government (HAYU dan GAMPIL) dalam pelayanan perizinan dan digitalisasi proses.

2. Kelemahan (Weakness)

a) Kekurangan sumber daya manusia;

b) Belum adanya sistem yang terintegrasi dengan OSS dan dinas teknis terkait;

c) Minimnya pengetahuan masyarakat dikarenakan sosialisasi penerapan e-government baru terbatas kepada kalangan aparatur pemerintah dan target group UMKM belum kepada masyarakat secara luas;

d) Adanya tumpang tindih peraturan pelayanan perizinan.

3. Peluang (Opportunities)

a) Adanya aplikasi berbasis website pelayanan perizinan online dari pemerintah pusat;

b) Adanya pelatihan-pelatihan yang diadakan BKPM RI dan DPM-PTSP Kota Bandung dalam hal pelayanan publik dan pelayanan perizinan online;

c) Teknologi informasi dan komunikasi dapat mengefektifkan dan mengefisienkan pelayanan kepada masyarakat. 


\section{Ancaman (Threats)}

a) Adanya hacker yang dapat melakukan kejahatan siber (cyber crime);

b) Kurangnya pemanfaatan aplikasi pelayanan perizinan online oleh masyarakat yang awam akan teknologi;

c) Jasa perantara (calo) yang mendegradasi kualitas pelayanan perizinan dengan menggunakan e-government; d) Keterlambatan rekomendasi teknis dari berbagai dinas terkait.

Berdasarkan hasil identifikasi kekuatan (Strengths), kelemahan (weakness), peluang (opportunities) dan ancaman (threats) penerapan e-government dalam meningkatkan kualitas pelayanan publik di DPM-PTSP Kota Bandung, maka matriks analisis SWOT dapat dilihat pada tabel berikut ini.

Tabel Matriks Analisis SWOT

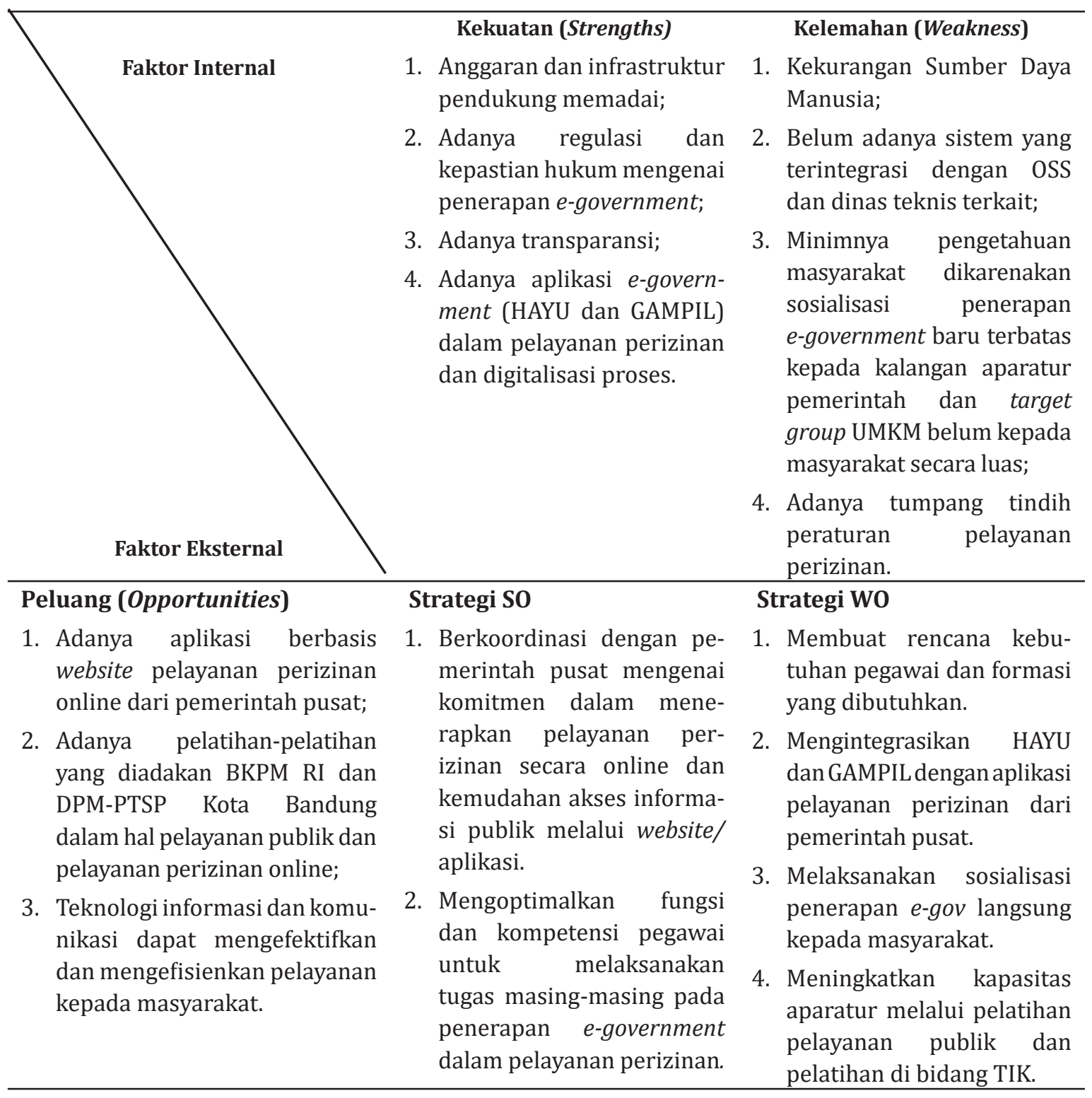




\begin{tabular}{|c|c|c|}
\hline Ancaman (Threats) & Strategi ST & Strategi WT \\
\hline $\begin{array}{l}\text { 1. Adanya hacker yang dapat } \\
\text { melakukan kejahatan siber } \\
\text { (cyber crime); } \\
\text { 2. Kurangnya pemanfaatan apli- } \\
\text { kasi pelayanan perizinan } \\
\text { online oleh masyarakat yang } \\
\text { awam akan teknologi; }\end{array}$ & $\begin{array}{l}\text { 1. Melaksanakan audit tingkat } \\
\text { keamanan aplikasi secara } \\
\text { berkala. } \\
\text { 2. Membuat loket khusus } \\
\text { bagi masyarakat yang } \\
\text { membutuhkan panduan } \\
\text { secara langsung. }\end{array}$ & $\begin{array}{l}\text { 1. Melaksanakan forum ko- } \\
\text { munikasi dan koordinasi } \\
\text { dengan perangkat dae- } \\
\text { rah terkait untuk memak- } \\
\text { simalkan kualitas proses } \\
\text { pelayanan perizinan berba- } \\
\text { sis e-government. }\end{array}$ \\
\hline $\begin{array}{l}\text { 3. Jasa perantara (calo) yang } \\
\text { mendegradasi kualitas pela- } \\
\text { yanan perizinan dengan } \\
\text { menggunakan e-government; } \\
\text { 4. Keterlambatan rekomendasi } \\
\text { teknis dari berbagai dinas } \\
\text { terkait. }\end{array}$ & $\begin{array}{l}\text { 3. Melaksanakan sosialisasi } \\
\text { lebih luas mengenai inovasi } \\
\text { digitalisasi proses untuk } \\
\text { mempersempit ruang ge- } \\
\text { rak calo. } \\
\text { 4. Bekerja sama dengan dinas } \\
\text { teknis untuk meningkatkan } \\
\text { kualitas pelayanan. }\end{array}$ & \\
\hline
\end{tabular}

Berdasarkan identifikasi faktor-faktor internal dan eksternal di atas, maka dapat diketahui sebelas isu srategis yang dapat digunakan untuk keberhasilan penerapan e-government dalam meningkatkan kualitas pelayanan publik di Dinas Penanaman Modal dan Pelayanan Terpadu Satu Pintu Kota Bandung. Strategi tersebut antara lain sebagai berikut.

1. Berkoordinasi dengan pemerintah pusat mengenai komitmen dalam menerapkan pelayanan perizinan secara online dan kemudahan akses informasi publik melalui website/aplikasi.

2. Mengoptimalkan fungsi dan kompetensi pegawai untuk melaksanakan tugas masing-masing pada penerapan e-government dalam pelayanan perizinan.

3. Membuat rencana kebutuhan pegawai dan formasi yang dibutuhkan.

4. Mengintegrasikan HAYU dan GAMPIL dengan aplikasi pelayanan perizinan dari pemerintah pusat.

5. Melaksanakan sosialisasi penerapan e-gov langsung kepada masyarakat.

6. Meningkatkan kapasitas aparatur melalui pelatihan pelayanan publik dan pelatihan di bidang TIK.
7. Melaksanakan audit tingkat keamanan aplikasi secara berkala.

8. Membuat loket khusus bagi masyarakat yang membutuhkan panduan secara langsung.

9. Melaksanakan sosialisasi lebih luas mengenai inovasi digitalisasi proses untuk mempersempit ruang gerak calo.

10. Bekerja sama dengan dinas teknis untuk meningkatkan kualitas pelayanan.

11. Melaksanakan forum komunikasi dan koordinasi dengan perangkat daerah terkait untuk memaksimalkan kualitas proses pelayanan perizinan berbasis e-government.

Berdasarkan beberapa isu yang telah diidentifikasi di atas, maka langkah selanjutnya adalah menguji dan menilai isu-isu strategis yang sudah teridentifikasi tersebut dengan menggunakan litmus test untuk mengukur tingkat kestrategisan dari masing-masing isu. Dari hasil analisis SWOT dan litmus test yang telah dilakukan, maka sebelas isu strategis dapat diklasifikasi berdasarkan kategori kestrategisannya sebagai berikut.

1. Isu sangat strategis, meliputi:

a. Berkoordinasi dengan pemerintah pusat mengenai komitmen dalam 
menerapkan pelayanan perizinan secara online dan kemudahan akses informasi publik melalui website/ aplikasi.

b. Mengintegrasikan HAYU dan GAMPIL dengan aplikasi pelayanan perizinan dari pemerintah pusat.

c. Melakukan sosialisasi penerapan e-government langsung kepada masyarakat.

d. Melaksanakan audit tingkat keamanan aplikasi secara berkala.

e. Bekerja sama dengan dinas teknis untuk meningkatkan kualitas pelayanan.

2. Isu cukup strategis, meliputi:

a. Membuat rencana kebutuhan pegawai dan formasi yang dibutuhkan.

b. Meningkatkan kapasitas aparatur melalui pelatihan pelayanan publik dan pelatihan di bidang TIK.

c. Melaksanakan sosialisasi lebih luas mengenai inovasi digitalisasi proses untuk mempersempit ruang gerak calo.

d. Melaksanakan forum komunikasi dan koordinasi dengan perangkat daerah terkait untuk memaksimalkan kualitas proses pelayanan perizinan berbasis e-government.

3. Isu bersifat operasional, meliputi:

a. Mengoptimalkan fungsi dan kompetensi pegawai untuk melaksanakan tugas masing-masing pada penerapan e-government dalam pelayanan perizinan.

b. Membuat loket khusus bagi masyarakat yang membutuhkan panduan secara langsung.

\section{SIMPULAN}

Penerapan e-government dalam meningkatkan kualitas pelayanan publik pada Dinas Penanaman Modal dan Pelayanan Terpadu Satu Pintu Kota Bandung sudah cukup baik dilihat dari tiga elemen sukses penerapan e-government (Indrajit, 2006), yaitu support, capacity, dan value. Pada elemen support penerapan e-government telah didukung oleh kebijakan e-government dari tingkat Pemerintah Pusat sampai ke Organisasi Perangkat Daerah, namun sosialisasi yang dilaksanakan masih belum maksimal. Pada elemen capacity penerapan e-government telah didukung oleh anggaran, infrastruktur teknologi dan kompetensi pegawai yang memadai. Pada elemen value penerapan e-government telah memberikan manfaat bagi masyarakat dan pemerintah.

Penerapan e-government dalam meningkatkan kualitas pelayanan publik pada Dinas Penanaman Modal dan Pelayanan Terpadu Satu Pintu Kota Bandung memiliki faktor pendukung dan penghambat, faktorfaktor pendukung di antaranya adalah anggaran dan infrastruktur memadai, adanya regulasi dan kepastian hukum, adanya transparansi, dan digitalisasi proses pelayanan perizinan, sedangkan faktor penghambatnya adalah kurangnya sumber daya manusia, belum adanya sistem yang terintegrasi, minimnya pengetahuan masyarakat, dan tumpang tindih peraturan perizinan.

Strategi yang sebaiknya digunakan untuk keberhasilan penerapan e-government dalam meningkatkan kualitas pelayanan publik di Dinas Penanaman Modal dan Pelayanan Terpadu Satu Pintu Kota Bandung adalah:

a. Berkoordinasi dengan pemerintah pusat mengenai komitmen dalam menerapkan pelayanan perizinan secara online dan kemudahan akses informasi publik melalui website/aplikasi. 
b. Mengintegrasikan HAYU dan GAMPIL dengan aplikasi pelayanan perizinan dari pemerintah pusat.

c. Melakukan sosialisasi penerapan e-government langsung kepada masyarakat.

d. Melaksanakan audit tingkat keamanan aplikasi secara berkala.

e. Bekerja sama dengan dinas teknis untuk meningkatkan kualitas pelayanan.

f. Membuat rencana kebutuhan pegawai dan formasi yang dibutuhkan

g. Meningkatkan kapasitas aparatur melalui pelatihan pelayanan publik dan pelatihan di bidang TIK.

h. Melaksanakan sosialisasi lebih luas mengenai inovasi digitalisasi proses untuk mempersempit ruang gerak calo.

i. Melaksanakan forum komunikasi dan koordinasi dengan perangkat daerah terkait untuk memaksimalkan kualitas proses pelayanan perizinan berbasis e-government

j. Mengoptimalkan fungsi dan kompetensi pegawai untuk melaksanakan tugas masing-masing pada penerapan e-government dalam pelayanan perizinan.

k. Membuat loket khusus bagi masyarakat yang membutuhkan panduan secara langsung.

\section{SARAN}

a. Dinas Penanaman Modal dan Pelayanan Terpadu Satu Pintu Kota Bandung diharapkan dapat menyesuaikan website/aplikasi pelayanan perizinan dengan pemerintah pusat dan bekerja sama dengan dinas teknis dengan tetap mengedepankan keamanan data dalam website/aplikasi, selain itu penulis juga menyarankan untuk mulai mengembangkan ke arah m-gov (mobile government). b. Dinas Penanaman Modal dan Pelayanan Terpadu Satu Pintu Kota Bandung sebaiknya memperluas ruang lingkup sosialisasi sehingga pengetahuan dan informasi tentang pelayanan perizinan tidak hanya diketahui oleh target group UMKM saja. Selain itu DPMPTSP Kota Bandung diharapkan segera menindaklanjuti perihal kekurangan sumber daya manusia (front office dan verifikator) untuk memaksimalkan pelayanan perizinan secara online kepada masyarakat.

\section{DAFTAR RUJUKAN}

Creswell, John W. 2014. Perencanaan Design (Pendekatan Kualitatif, Kuantitatif, dan Mixed). Yogyakarta: Pustaka Pelajar.

Effendi, Khasan. 2010. Memadukan Metode Kuantitatif dan Kualitatif. Bandung: CV. Indra Prahasta.

Ibrahim, Amin. 2008. Teori dan Konsep Pelayanan Publik Serta Implementasinya. Bandung: CV. Mandar Maju.

Indrajit, R. E. (2004). Strategi Pembangunan dan Pengembangan Sistem Pelayanan Publik Berbasis Teknologi Digital. Yogyakarta: Andi.

Indrajit, R. E., Rudianto, D., \& Zainuddin, A. (2007). Electronic Government in Action Strategi Implementasi di Berbagai Negara. Bandung: Aptikom.

Nazir, Moh. 2014. Metode Penelitian. Bogor: Ghalia Indonesia.

Rangkuti, Freddy. 2014. Analisis SWOT Teknik Membedah Kasus Bisnis. Jakarta: Gramedia Pustaka Utama.

Sinambela, Lijan Poltak. 2010. Reformasi Pelayanan Publik. Jakarta: Bumi Aksara.

Sumanto, 2014. Teori dan Aplikasi Metode Penelitian. Yogyakarta: Centre of Academic Publishing Service (CAPS).

Sumaryadi, I Nyoman. 2010. Sosiologi Pemerintahan: Dari Perspektif Pelayanan, Pemberdayaan, Interaksi, dan Sistem 
Kepemimpinan Pemerintahan Indonesia. Bogor: Ghalia Indonesia.

Wasistiono, Sadu. 2017. Perkembangan Ilmu Pemerintahan (Dari Klasik Sampai ke Kontemporer). Jatinangor: IPDN Press

\section{Jurnal}

Minhwa Lee, dkk. 2018. How to Respond to the Fourth Industrial Revolution, or the Second Information Technology Revolution? Dynamic New Combinations between Technology, Market, and Society through Open Innovation. Journal of open innovation: Technology, Market, and complexity. doi: 10.3390/joitmc4030021

\section{Peraturan Perundang-Undangan}

Undang-Undang No. 25 Tahun 2007 tentang Penanaman Modal.

Undang-Undang No. 23 Tahun 2014 tentang Pemerintahan Daerah.

Peraturan Presiden No. 97 Tahun 2014 tentang Penyelenggaraan Pelayanan Terpadu Satu Pintu.

Instruksi Presiden No. 3 Tahun 2003 tentang Kebijakan dan Strategi Nasional Pengembangan e-Government.

Peraturan Menteri Dalam Negeri No. 138 Tahun 2017 Penyelenggaraan Pelayanan Terpadu Satu Pintu Daerah.
Peraturan Kepala Badan Koordinasi Penanaman Modal Republik Indonesia No. 15 Tahun 2015 tentang Pedoman dan Tata Cara Perizinan dan Non-perizinan Penanaman Modal.

Peraturan Daerah Kota Bandung No. 8 Tahun 2016 tentang Pembentukan dan Susunan Perangkat Daerah Kota Bandung.

Peraturan Wali Kota Bandung No. 1338 Tahun 2017 tentang Tata Kelola Teknologi Informasi dan Komunikasi.

\section{Website}

https: / / ww w.liputan6.com / tekno / read/2499161/opini-cegah-penyelewengan-dengan-e-government-hybrid-cloud-04 Mei 2016 diakses pada 1 November 2019

https: //www.republika.co.id/berita/nasional/ u mu m / 16 / 10 / 19/ of ab 9 m 382 - eGovernment-masih-sulit-diterapkandaerah-19 oktober 2016 diakses pada 1 November 2019

https: //www.kompasiana.com/nurulpurnam a07/5512a8bf813311476cbc601f/egovernment-system-dalam-pelayananpublik-30 Juli 2012 diakses pada 1 November 2019 
Virioner - Vol. $13 \backslash$ No. $2 \backslash$ Agustus 2021 